\title{
Observations of fluorescent aerosol-cloud interactions in the free troposphere at the High-Altitude Research Station Jungfraujoch
}

\author{
I. Crawford ${ }^{1}$, G. Lloyd ${ }^{1,2}$, E. Herrmann ${ }^{3}$, C. R. Hoyle ${ }^{3,4}$, K. N. Bower ${ }^{1}$, P. J. Connolly ${ }^{1}$, M. J. Flynn ${ }^{1}$, P. H. Kaye ${ }^{5}$, \\ T. W. Choularton ${ }^{1}$, and M. W. Gallagher ${ }^{1}$ \\ ${ }^{1}$ Centre for Atmospheric Science, SEAES, University of Manchester, Manchester, UK \\ ${ }^{2}$ NCAS, National Centre for Atmospheric Science, University of Manchester, Manchester, UK \\ ${ }^{3}$ Laboratory of Atmospheric Chemistry, Paul Scherrer Institute, Villigen, Switzerland \\ ${ }^{4}$ WSL Institute for Snow and Avalanche Research SLF, Davos, Switzerland \\ ${ }^{5}$ Science and Technology Research Institute, University of Hertfordshire, Hatfield, UK \\ Correspondence to: I. Crawford (i.crawford@manchester.ac.uk)
}

Received: 31 July 2015 - Published in Atmos. Chem. Phys. Discuss.: 25 September 2015

Revised: 5 February 2016 - Accepted: 9 February 2016 - Published: 26 February 2016

\begin{abstract}
The fluorescent nature of aerosol at a highaltitude Alpine site was studied using a wide-band integrated bioaerosol (WIBS-4) single particle multi-channel ultraviolet - light-induced fluorescence (UV-LIF) spectrometer. This was supported by comprehensive cloud microphysics and meteorological measurements with the aims of cataloguing concentrations of bio-fluorescent aerosols at this highaltitude site and also investigating possible influences of UVfluorescent particle types on cloud-aerosol processes.

Analysis of background free tropospheric air masses, using a total aerosol inlet, showed there to be a minor increase in the fluorescent aerosol fraction during in-cloud cases compared to out-of-cloud cases. The size dependence of the fluorescent aerosol fraction showed the larger aerosol to be more likely to be fluorescent with $80 \%$ of $10 \mu \mathrm{m}$ particles being fluorescent. Whilst the fluorescent particles were in the minority $\left(N_{\mathrm{Fl}} / N_{\mathrm{All}}=0.27 \pm 0.19\right)$, a new hierarchical agglomerative cluster analysis approach, Crawford et al. (2015) revealed the majority of the fluorescent aerosols were likely to be representative of fluorescent mineral dust. A minor episodic contribution from a cluster likely to be representative of primary biological aerosol particles (PBAP) was also observed with a wintertime baseline concentration of $0.1 \pm 0.4 \mathrm{~L}^{-1}$. Given the low concentration of this cluster and the typically low ice-active fraction of studied PBAP (e.g. pseudomonas syringae), we suggest that the contribution to the observed ice crystal concentration at this location is not significant during the wintertime.
\end{abstract}

\section{Introduction}

The formation of cloud particles and their subsequent interactions with the atmosphere are highly uncertain, with the formation and evolution of mixed-phase and glaciated clouds being poorly understood (Penner et al., 2001). Improving our understanding of primary ice nucleation is critical in underpinning these uncertainties, as even modest concentrations of primary ice can result in the rapid glaciation via secondary ice production mechanisms and subsequently cause precipitation in mixed-phase clouds, drastically changing cloud lifetime (Lloyd et al., 2015; Crawford et al., 2012; Crosier et al., 2011); e.g. Crawford et al. (2012) showed that low concentrations of primary ice $\left(0.01 \mathrm{~L}^{-1}\right)$ resulted in the rapid glaciation of a shallow convective wintertime cumulus via the Hallet-Mossop ice multiplication process.

Many candidate aerosols have been assessed for their heterogeneous ice nucleating ability with a particular emphasis being placed on mineral dust and primary biological aerosols. The ice nucleating efficiency of many naturally occurring and surrogate dust aerosols have been investigated and they are generally considered to be efficient ice nuclei with observations of ice activation occurring over water subsaturated and supersaturated conditions at temperatures below $-10^{\circ} \mathrm{C}$ (Hoose and Möhler, 2012). The influence of accumulated coatings such as secondary organic aerosol, sulfuric acid, and ammonium sulfate through atmospheric processing have also been assessed, where it was found these act 
to significantly increase the saturation ratio required for ice nucleation, effectively deactivating an otherwise ice-active mineral dust (Chernoff et al., 2010; Koehler et al., 2010; Sullivan et al., 2010; Cziczo et al., 2009; Eastwood et al., 2008; Möhler et al., 2008b). Saharan desert dust was observed during an experiment in a Florida region where it was suggested that the dust may have been acting as an effective high-temperature ice nucleus resulting in the observed glaciation of an altocumulus cloud at $-5^{\circ} \mathrm{C}$ (Sassen et al., 2003). Saharan desert dust was also found to be the major non-volatile component of ice crystal residuals in cirrus over the Alps (Heintzenberg et al., 1996). The high ice nucleation efficiency of mineral dusts and their capacity for long-range transport therefore make them a potentially significant component in the formation and modification of clouds worldwide.

Certain primary biological aerosol particles (PBAP) exhibit the ability to nucleate ice and it has recently been suggested that ice-active PBAP may have evolved over geological timescales to enhance rainfall, fostering an environment beneficial to the growth of plants and microorganisms through the so-called bioprecipitation feedback cycle (Morris et al., 2014). A small number of bacterial strains, fungal spores, and rusts have been identified as ice active at temperatures warmer than $-10^{\circ} \mathrm{C}$ due to the presence of an ice nucleating protein in the outer cell wall, which is structurally similar to ice, facilitating ice growth (Kajava and Lindow, 1993; Govindarajan and Lindow, 1988; Hoose and Möhler, 2012). However, of the ice-active bacterial strains studied so far only a small fraction nucleates ice at very warm temperature, e.g. Möhler et al. (2008a) demonstrated that Pseudomonas syringae have a maximum ice-active fraction of 0.005 at $-9.7^{\circ} \mathrm{C}$. However, they may still play a significant role in the formation and modification of clouds; plant surface derived bacterial aerosol can be transported to the higher levels of the atmosphere in high concentrations as a result of heavy rainfall and storm generated uplift (Crawford et al., 2014; DeLeon-Rodriguez et al., 2013; Huffman et al., 2013).

The High-Altitude Research Station Jungfraujoch has hosted several intensive measurement campaigns to study cloud-aerosol interactions (e.g. Targino et al., 2009; Choularton et al., 2008; Cozic et al., 2007; Verheggen et al., 2007). Previous measurements at the site have found there to be an enhancement of mineral dust in cloud particle residuals compared to interstitial aerosol measurements (Kamphus et al., 2010). This study also deployed a portable ice nucleation chamber during June 2009, where two Saharan dust events (SDEs) were reported. During the SDEs it was found that ice nuclei concentrations were correlated with larger aerosol $\left(D_{\mathrm{p}}>0.5 \mu \mathrm{m}\right)$ with reported deposition-mode ice nuclei concentrations of up to several hundred per litre. This is discussed in more detail in the companion paper to this study by Lloyd et al. (2015). In this study, we present contemporaneous aerosol and cloud microphysics measurements at the same site to characterise the fluorescent constituents of aerosol and their possible role in cloud processes.

\section{Methods}

\subsection{Site description}

During January and February 2014, the Ice NUcleation Process Investigation And Quantification (INUPIAQ) project was conducted at the High-Altitude Research Station Jungfraujoch (JFJ; $3580 \mathrm{~m}$ a.s.l. - above sea level; $46.55^{\circ} \mathrm{N}$, $7.98^{\circ} \mathrm{E}$ ) in Switzerland to investigate the influence of a range of aerosol types on ice crystal number concentration alongside secondary ice processes in natural supercooled clouds. The facility is situated on a mountain ridge in between the peaks of the Jungfrau and Mönch with the Great Aletsch glacier, the largest in the Alps, to the south and is well away from major anthropogenic pollution sources. The JFJ site is enveloped by cloud for approximately $37 \%$ of the time making it ideal for studying cloud-aerosol interactions, with the site residing in the free troposphere for most of the time during the wintertime (Baltensperger et al., 1998; Herrmann et al., 2015).

\subsection{Instrumentation and inlets}

Fluorescent aerosol number-size distributions were measured using a Wideband Integrated Bioaerosol Spectrometer version 4 (WIBS-4; University of Hertfordshire) on a single particle basis and designed primarily for identifying bio-fluorphores. A full technical description can be found in Kaye et al. (2005), while various applications and analysis approaches including monitoring at high-altitude sites can be found in Crawford et al. (2014), Gabey et al. (2013), and Stanley et al. (2011). A brief description of the instrument is now given. The WIBS-4 spectrometer exploits the principle of ultraviolet light-induced fluorescence where a particle of interest is excited with UV radiation and the resultant fluorescence is detected, with fluorescence being an indicator that the particle may be biological. In the WIBS4 aerosol is drawn into the sample volume and illuminated by a $635 \mathrm{~nm}$ laser and the resultant forward scattered light is used to determine the particle size and shape using a quadrant detector (Kaye et al., 2005). Side scattered light is collected and sequentially triggers two xenon flash lamps, filtered to excite the sampled particle at 280 and $370 \mathrm{~nm}$. The first lamp is pulsed and the resultant fluorescence is collected, filtered and passed to two fluorescence detectors. The detectors are filtered to measure fluorescence over two detection bands (320-400 and 410-650 $\mathrm{nm}$ ), which are then recorded. The second flash lamp is then triggered and the fluorescence detected by the second band is recorded. The whole process takes approximately $25 \mu$ s and the instrument has a maximum particle analysis rate of 125 particles s $^{-1}$. This provides three measurements of particle fluorescence 
over two excitation wavelengths, particle size, and an approximation of particle shape, all on a single particle basis (Kaye et al., 2005). The excitation and detection wavelengths have been selected to conform to auto-fluorescence bands of common components of biological materials (e.g. proteins, tryptophan and Nicotinamide adenine dinucleotide (NADH); the latter is related to cell metabolism) such that they can be discriminated from non-biological, non-fluorescent particles (Kaye et al., 2005). Due to detector sensitivity and background fluorescence within the WIBS-4 optical chamber, the fluorescence of aerosol with diameters $D_{\mathrm{p}}<0.8 \mu \mathrm{m}$ cannot be accurately measured, and the counting efficiency decreases (Gabey et al., 2011). Therefore, the analysis presented here is limited to aerosols with diameters greater than $0.8 \mu \mathrm{m}$, unless otherwise stated. Whilst WIBS-4 instruments have many advantages over traditional methods, ultraviolet - light-induced fluorescence (UV-LIF) spectrometers, limitations include difficulties in discriminating different classes of biological particles unambiguously and fluorescent non-biological aerosols must be identified. Fluorescence of some mineral dusts was examined by Pöhlker et al. (2012), who characterised their weak fluorescence properties allowing them to be generally discriminated from common PBAP using UV-LIF. In this study we use a new hierarchical agglomerative data processing method for WIBS-4 UV-LIF measurements to discriminate between particle types and the methods used are described in Sect. 4. A detailed discussion of this can be found in Crawford et al. (2015).

The WIBS-4 sampled from a total inlet (TI), which is now described. The TI samples all particles with $D_{\mathrm{p}}<40 \mu \mathrm{m}$ and for wind speeds $<20 \mathrm{~m} \mathrm{~s}^{-1}$. The sampled air is first heated to $+20^{\circ} \mathrm{C}$, evaporating droplets and ice crystals such that their residuals are sampled along with any interstitial aerosol (Weingartner et al., 1999).

A custom built scanning mobility particle sizer (SMPS) has sampled continuously from the TI since 2008. It consists of a differential mobility analyser (DMA; TSI 3071) and a condensation particle counter (CPC; TSI 3775) and it measures the aerosol size distribution between 20 and $600 \mathrm{~nm}$ in diameter with $6 \mathrm{~min}$ time resolution (Herrmann et al., 2015). This was used to determine the origin of the sampled air masses, using the concentration of particles larger then $90 \mathrm{~nm}$ in diameter as described in Sect. 3.1 and Herrmann et al. (2015).

Comprehensive cloud microphysics measurements were made at the site and are described in Lloyd et al. (2015). In this study, cloud droplet and ice crystal number concentrations were measured, respectively, with a Cloud Droplet Probe (CDP-100; Droplet Measurement Technologies; DMT), described by Lance et al. (2010), and a 3View Cloud Particle Imager (3V-CPI). The CDP-100 is an optical scattering spectrometer able to size particles in the range $2<D_{\mathrm{p}}<50 \mu \mathrm{m}$, whilst the $3 \mathrm{~V}$-CPI is an integrated 2D Stereo (2DS) LED imaging spectrometer and Cloud Particle Imaging (CPI), charge-coupled device imaging spectrom- eter with resolutions of 10 and $2.3 \mu \mathrm{m}$, respectively (Lawson et al., 2015). These are capable of measuring ice particle size distributions between 10 and $1280 \mu \mathrm{m}$ and able to discriminate particle habit (based on shape analysis) for particles greater than approximately 25-30 $\mu \mathrm{m}$. Details of the analysis techniques used for these instruments are provided in Crosier et al. (2014) and Lloyd et al. (2015).

\section{Results}

During the experiment, there were two extended SDEs (00:00 CET, 1 February-00:00 CET, 2 February and 04:30 CET, 18 February-19:00 CET, 19 February). In this paper we focus on the period outside these events in order to characterise the behaviour of high-Alpine fluorescent aerosol under typical wintertime background conditions. Discussion of the SDEs will be described elsewhere; $5 \mathrm{~min}$ integration periods are used in all analysis unless otherwise stated.

\subsection{Meteorological conditions}

An overview of the meteorological conditions at the JFJ site over the background period 6-18 February is provided in Fig. 1. Average temperatures of $-11.3 \pm 4.3$ and $-14.6 \pm 3.3^{\circ} \mathrm{C}$ were reported for out-of-cloud and in-cloud periods, respectively, with wind speeds of $5.2 \pm 3.3 \mathrm{~m} \mathrm{~s}^{-1}$. Daily Hybrid Single Particle Lagrangian Integrated Trajectory Model (HYSPLIT) back trajectory analysis (Fig. 2) showed the majority of air masses to have passed over the Atlantic Ocean in the preceding $72 \mathrm{~h}$ during this period. Analysis of wind speed and direction shows the highest concentrations of fluorescent aerosols occur when the wind is coming from the south-east for wind speeds in excess of $15 \mathrm{~m} \mathrm{~s}^{-1}$, i.e. coincident with flow up from the Aletsch glacier.

We use the approach of Herrmann et al. (2015) to determine the origin of the sampled air masses so that boundary layer influenced air masses can be excluded from analysis; here we use the concentration of particles larger than $90 \mathrm{~nm}$ in diameter $\left(N_{90}\right)$ as described in Herrmann et al. (2015) to distinguish periods of free tropospheric conditions from those influenced by planetary boundary layer (PBL). They found that $N_{90}=40 \mathrm{~cm}^{-3}$ was a good approximation to describe free tropospheric background aerosol across all seasons, with periods influenced by the PBL resulting in $N_{90}$ concentrations of several hundred to $1000 \mathrm{~cm}^{-3}$. These values were found to be lower in winter, so we use $N_{90}<30 \mathrm{~cm}^{-3}$ to be representative of background FT conditions and $N_{90}<50 \mathrm{~cm}^{-3}$ to be representative of FT-like conditions during the sampling period as described in Herrmann et al. (2015). A time series of the SMPS $N_{90}$ concentration for the analysis period is presented in Fig. 3 where the background FT condition of $N_{90}<30 \mathrm{~cm}^{-3}$ is met $66.2 \%$ of the time and FT-like conditions where $N_{90}<50 \mathrm{~cm}^{-3}$ is 


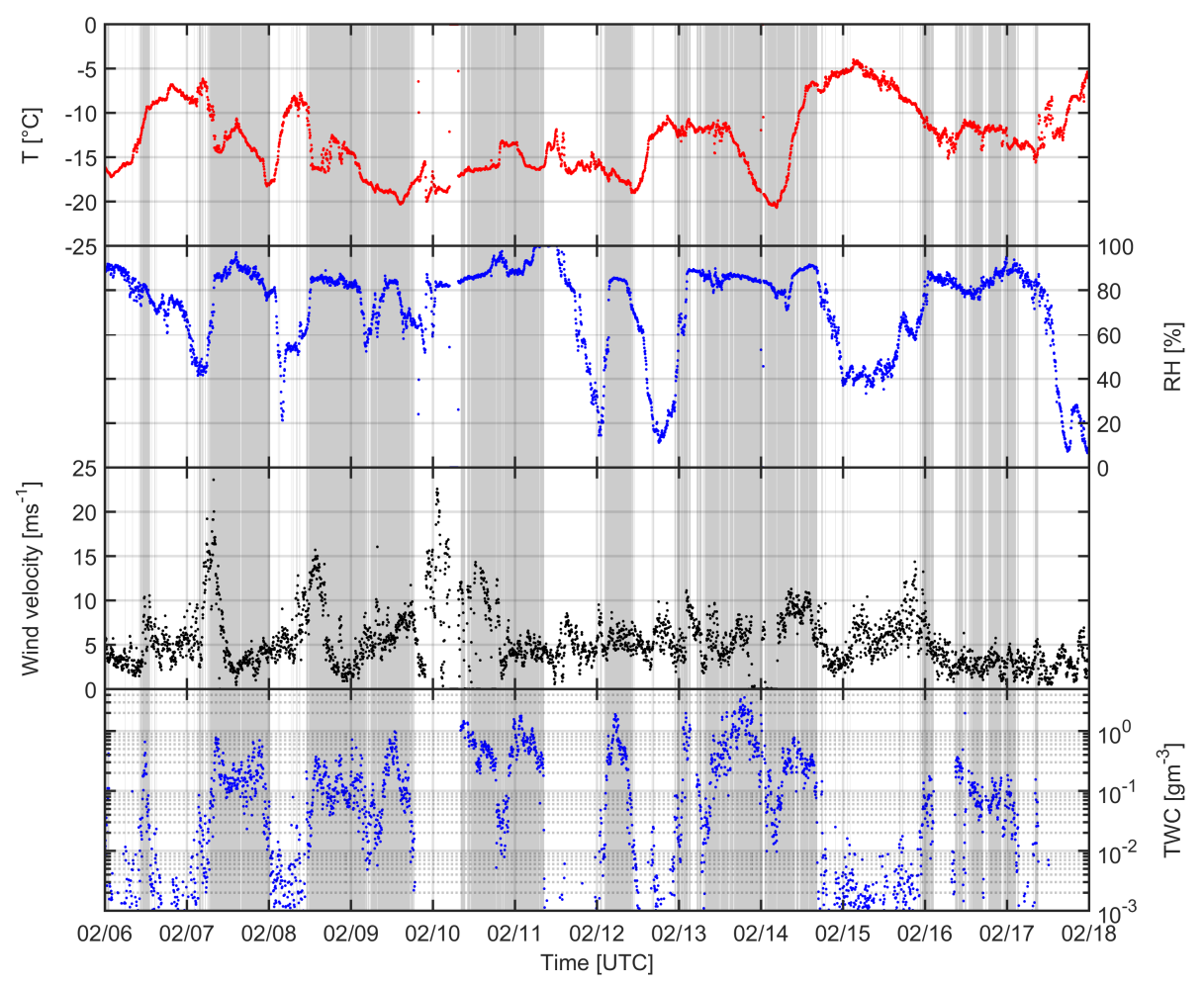

Figure 1. Time series of meteorological data and total water content at the JFJ site for the period 6-18 February. Grey shaded areas denote in cloud periods $\left(\mathrm{TWC} \geq 0.01 \mathrm{~g} \mathrm{~m}^{-3}\right.$ ).

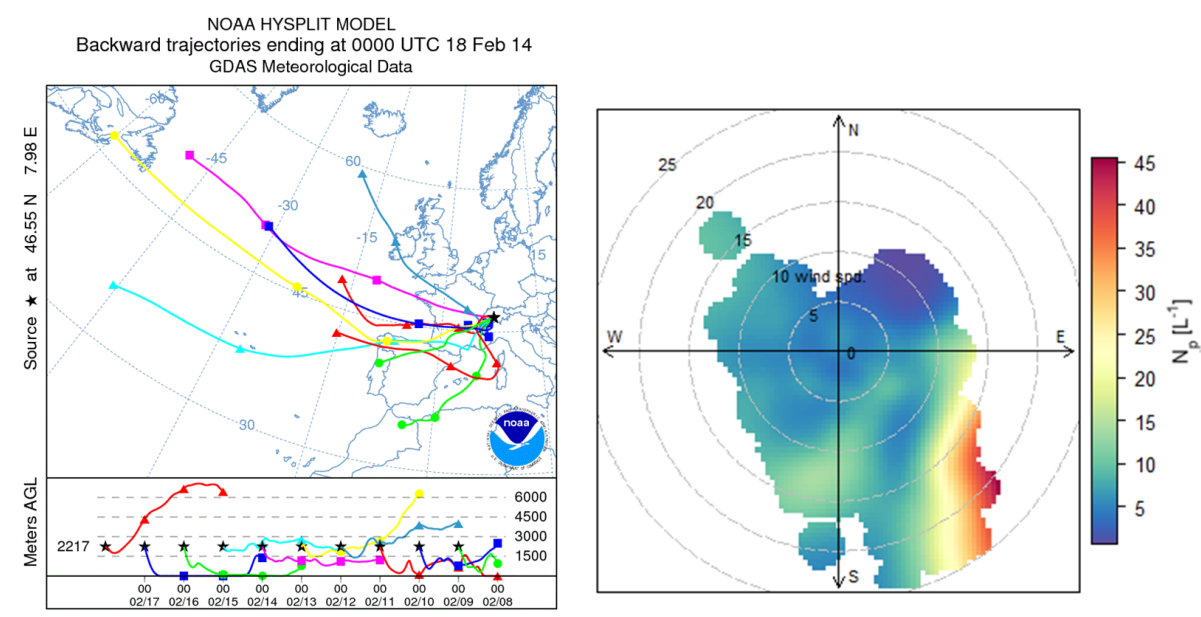

Figure 2. Left panel: HYSPLIT back trajectories for the period 8-18 February. Right panel: fluorescent aerosol concentration $\left(\mathrm{L}^{-1}\right)$ dependence on wind speed and direction. Wind speed denoted by concentric rings $\left(5 \mathrm{~m} \mathrm{~s}^{-1}\right.$ per ring).

met $88.4 \%$ of the time. Periods with $N_{90}>50 \mathrm{~cm}^{-3}$, such as the extended period between 09:00 CET 15 February09:00 CET 16 February, are excluded from analysis.

\subsection{Background observations of fluorescent aerosol}

To assess the background conditions during the sampling period, we have compared the aerosol data collected during the campaign to long-term measurements made during February at the site between 2009 and 2014. Figure 4 shows median, 25th percentile, and 75th percentile SMPS and Optical Particle Counter (OPC) size-resolved concen- 


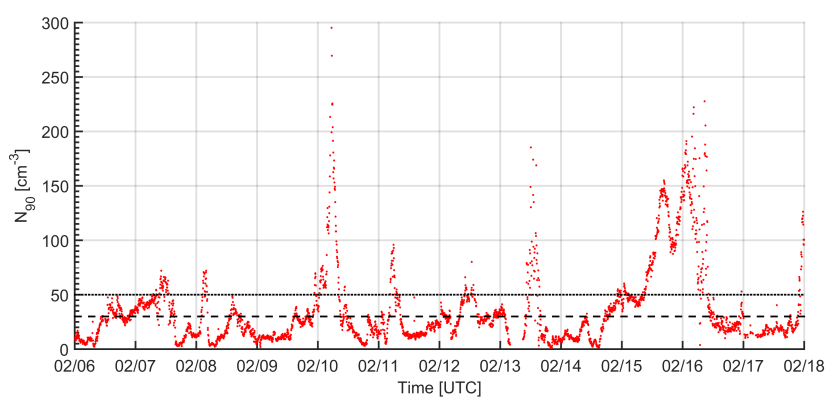

Figure 3. Time series of $N_{90}$ concentration for the analysis period. Dashed line denotes the $30 \mathrm{~cm}^{-3}$ background concentration described in Herrmann et al. (2015); the dotted line denotes this $50 \mathrm{~cm}^{-3}$ threshold used to distinguish free tropospheric conditions.

tration measurements made during the month of February from 2009 to 2014, which we compare to the campaign median SMPS, OPC, and WIBS non-fluorescent and fluorescent size-resolved concentrations, where the SMPS reports mobility diameter and the OPC and WIBS report optical diameter. It can be seen that the campaign measurements typically lie within the range of the 25th percentile and median values of the long-term measurements during February at the site, suggesting that the measurement period can be considered to be representative of the typical background aerosol concentration at the Jungfraujoch during wintertime.

The average out-of-cloud total coarse aerosol, $N_{\text {All }}$, and total fluorescent aerosol concentrations, $N_{\mathrm{Fl}}$, measured by the WIBS-4 were $30.6 \pm 19.3$ and $6.3 \pm 5.7 \mathrm{~L}^{-1}$, respectively, for the period 6-18 February, as shown in Fig. 5 (5 min averages).

To investigate the potential interaction of fluorescent aerosol with clouds, we have studied the fluorescent aerosol concentration fraction $\left(N_{\mathrm{Fl}} / N_{\mathrm{All}}\right)$ over different temperature regimes for out-of-cloud, mixed-phase, and glaciated conditions as summarised in Fig. 6. Here we define out of cloud as all periods where the total water content (TWC) is less than $0.01 \mathrm{~g} \mathrm{~m}^{-3}$, mixed phase as all periods where the TWC $\geq 0.01 \mathrm{~g} \mathrm{~m}^{-3}$ and ice mass fraction (IMF) is less than 0.9 , and glaciated as all periods where $\mathrm{TWC} \geq 0.01 \mathrm{~g} \mathrm{~m}^{-3}$ and $\mathrm{IMF} \geq 0.9$.

To test the statistical significance of these results we have performed a one-way analysis of variance (ANOVA) analysis on subsets of the data, which we now describe; first we assessed the influence of temperature separately for in cloud (TWC $\geq 0.01 \mathrm{~g} \mathrm{~m}^{-3}$ ) and out-of-cloud (TWC $<0.01 \mathrm{~g} \mathrm{~m}^{-3}$ ) conditions where it can be seen in Fig. 6 that in each case the fluorescent fraction decreases with decreasing temperature. The ANOVA analysis returns small $p$ values $\left(4 \times 10^{-6}\right.$ and $1 \times 10^{-4}$ for the out-of-cloud and in-cloud cases, respectively), which indicates that the means are statistically significantly different; however, the spread in values are large; next we assessed the influence of the presence of cloud on fluorescent fraction at each temperature by comparing the out-of-

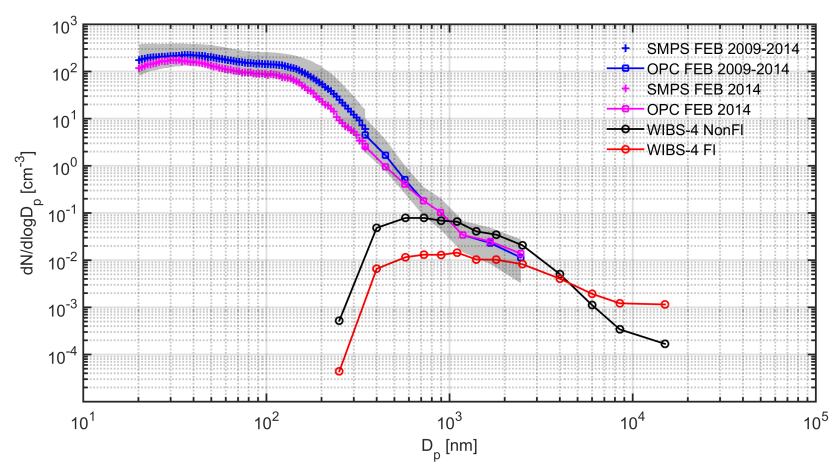

Figure 4. Comparison of long-term median SMPS and OPC number-size distribution measurements made during February 2009 to 2014 to those made during the 2014 campaign. Grey shaded area represents the quartiles of the long-term measurements.

cloud and in-cloud cases for each temperature regime. This shows that the fluorescent fraction is generally increased in clouds (Fig. 7, top panels) with $p$ values indicating that the means are significantly different $(p<0.05)$; finally we assessed the influence of cloud type on the fluorescent fraction for each temperature regime as shown in Fig. 7. Here it can be seen that the fluorescent fractions are generally greater in mixed-phase conditions than in glaciated conditions.

In summary it can be seen across all temperature regimes that the average in-cloud fluorescent aerosol fractions were slightly greater than for out-of-cloud conditions with the largest increase occurring during mixed-phase conditions. The observed increase in the fluorescent aerosol fraction in mixed-phase conditions is generally a result of a reduction in the non-fluorescent aerosol concentration relative to the corresponding out-of-cloud cases, rather than an enhancement in the fluorescent aerosol concentration. One possible explanation for this is that non-fluorescent aerosol has been removed via Cloud Condensation Nuclei (CCN) activation and lost in precipitating raindrops in mixed-phase clouds as this is not pronounced in the glaciated cases; however, caution must be applied when interpreting the results of this general approach as the differences in fluorescent aerosol fraction may be caused by differences in the sampled air masses for each case.

Figure 8 shows the fluorescent aerosol fraction for cloud events persisting for a minimum of $30 \mathrm{~min}$ in duration with mean, minimum, and maximum observed average fluorescent aerosol fractions of $0.27 \pm 0.12,0.05$, and 0.49 , respectively, over 31 separate cloud events. It can be seen that many of the clouds feature large variations in fluorescent aerosol fraction, while others have relatively little variation, which may be an effect of sampling several different air masses during a single cloud event. The correlation between mean and median fluorescent aerosol fraction and the following meteorological and cloud microphysical parameters were investigated: IMF, TWC, ice water content (IWC), liquid wa- 


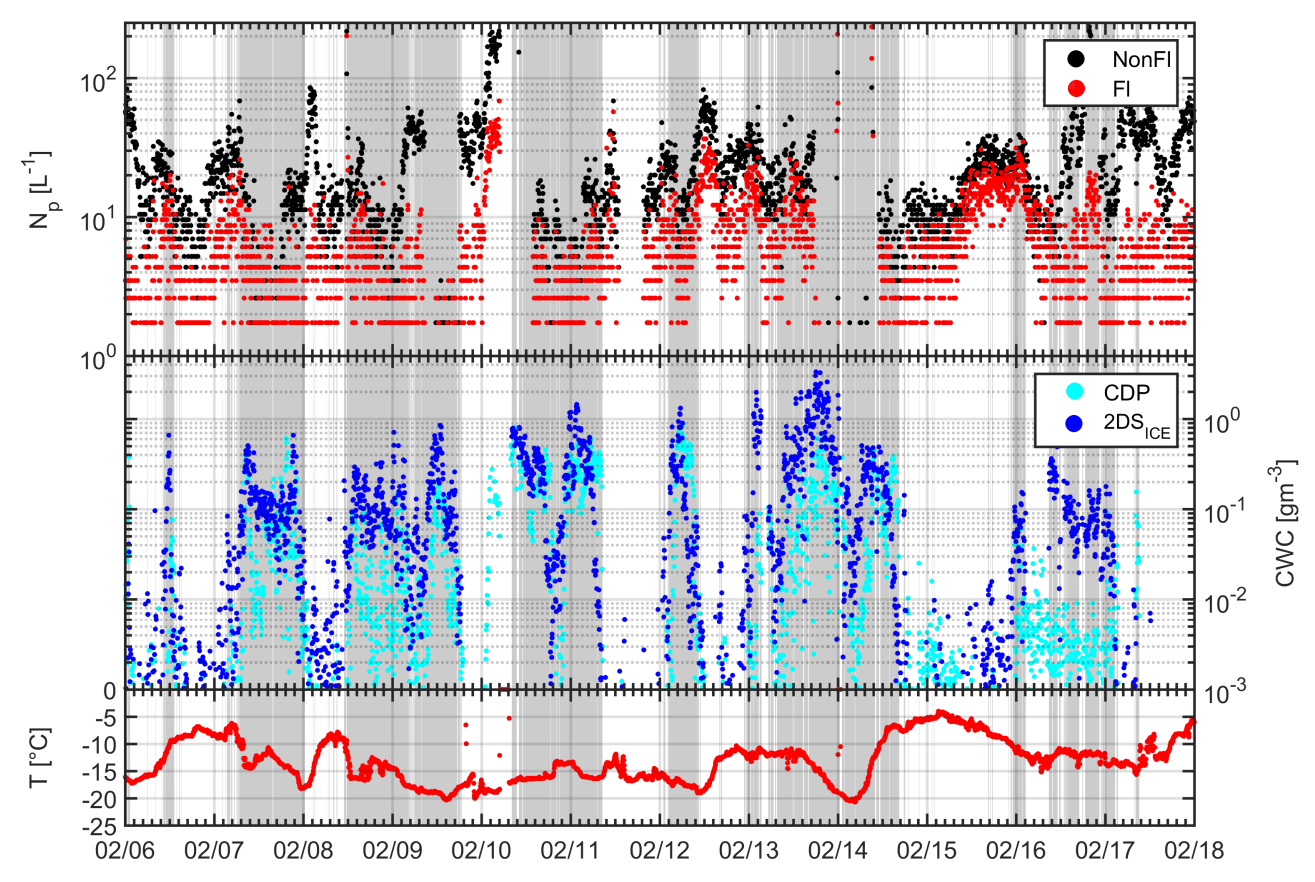

Figure 5. Top panel: time series of total fluorescent, $N_{\mathrm{Fl}}$, (red) and total non-fluorescent, $N_{\mathrm{NonFl}}$, (black) aerosol concentrations measured with the WIBS-4 sampling from the total inlet (TI). Middle panel: liquid (cyan) and ice (blue) water contents measured with the CDP-100 and 3V-CPI-2DS. Bottom panel: temperature. Box and whiskers denote 5th, 25th, 50th, 75th, and 95th percentiles. Grey shaded areas denote in cloud periods ( $\mathrm{TWC} \geq 0.01 \mathrm{~g} \mathrm{~m}^{-3}$ ).

ter content (LWC), ice and droplet concentrations, temperature, and wind speed and direction. A scatter plot of the mean (black + ) and median (red diamonds) values for each cloud event is shown in Fig. 9, along with the corresponding $r^{2}$ value where no significant correlation between parameters is observed. No apparent trend is observed between the fluorescent aerosol fractions and contemporaneous mean meteorological or cloud microphysical parameters, suggesting that particle fluorescence does not impact cloud evolution or formation.

The majority of cloud events occur in the $-15^{\circ} \mathrm{C} \leq T<-10^{\circ} \mathrm{C}$ regime: Fig. 10 shows the average fluorescent and non-fluorescent particle size distributions for out-of-cloud, mixed-phase, and glaciated conditions in this temperature regime. In each case the single mode of the distribution occurs at $0.58 \mu \mathrm{m}$; however, the counting efficiency for particles $D_{\mathrm{p}}<0.8 \mu \mathrm{m}$ is low (Gabey et al., 2011), so the true mode is likely to be much smaller when measured with, e.g., an SMPS as indicated in Fig. 4.

Figure 11 shows the size dependence of the fluorescent aerosol fraction for the three studied temperature regimes for out-of-cloud, mixed-phase, and glaciated conditions. In each case, it was observed that the fluorescent aerosol fraction increases with size, with approximately $80 \%$ of $10 \mu \mathrm{m}$ parti- cles being fluorescent in nature, with the fluorescent aerosol fraction decreasing to approximately $20 \%$ for $1 \mu \mathrm{m}$ particles. Caution must be applied when interpreting the sub-micron fluorescent aerosol fraction due to the reduced fluorescent counting efficiency for particles $D_{\mathrm{p}}<0.8 \mu \mathrm{m}$ (Gabey et al., 2011), which may lead to an underestimation of the fluorescent aerosol fraction at small sizes. For clarity and ease of comparison only the mean ratios for each case are presented here. Individual plots for each case showing the mean and standard deviation of the fluorescent ratio are provided as a Supplement.

\section{Analysis of fluorescent aerosol characteristics}

To probe the nature of the fluorescent aerosols, the single particle data from the period 6-18 February (approximately 27000 fluorescent particles) were clustered using the Ward hierarchical agglomerative cluster analysis linkage and $Z$-score normalisation technique with the log of the diameter and particle asymmetry factors (AF) used to improve the symmetry of the cluster distribution. For further details on the hierarchical agglomerative cluster analysis method used here see Crawford et al. (2015). The CalinskiHarabasz metric was used to determine the optimum clus- 


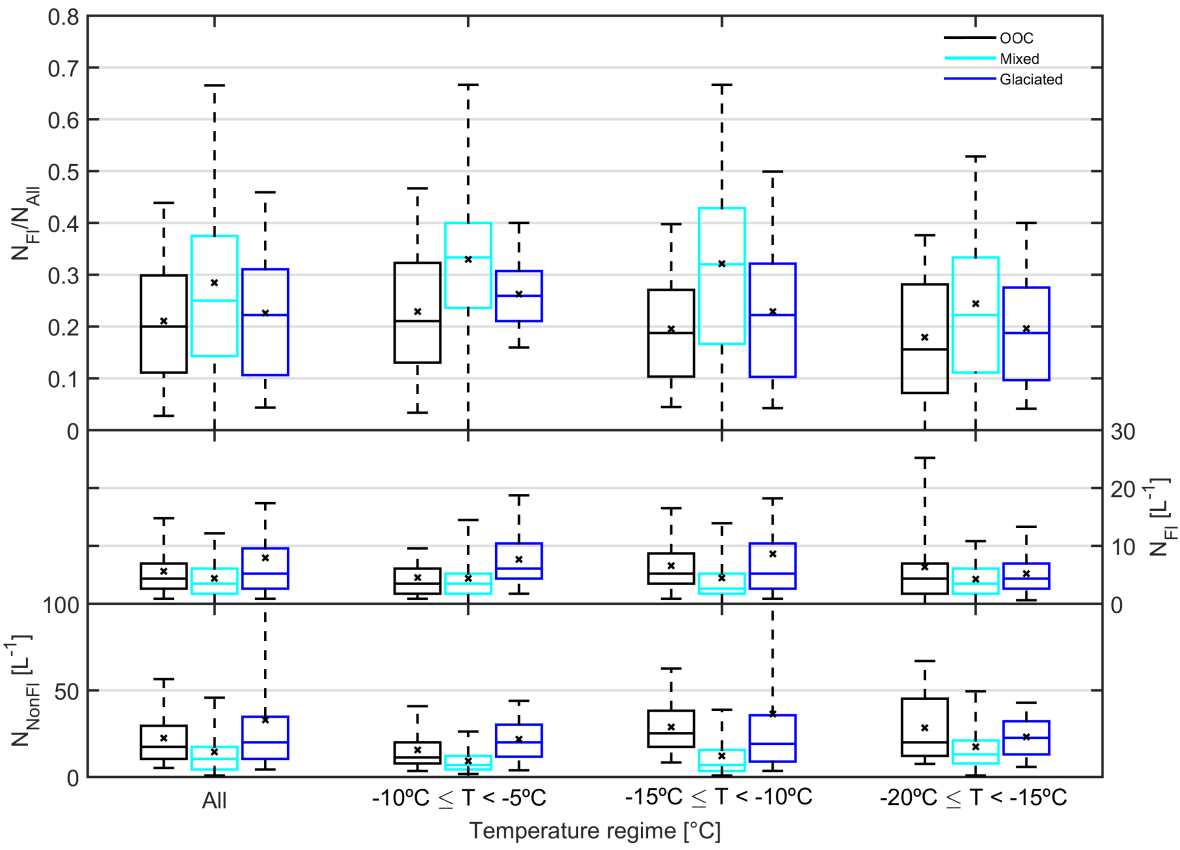

Figure 6. Top panel: fluorescent to total aerosol concentration ratio for out-of-cloud (black, TWC $<0.01 \mathrm{~g} \mathrm{~m}^{-3}$ ), mixed-phase (cyan, TWC $\geq 0.01 \mathrm{~g} \mathrm{~m}^{-3}$ and IMF $<0.9$ ), and glaciated (blue, TWC $\geq 0.01 \mathrm{~g} \mathrm{~m}^{-3}$ and IMF $\geq 0.9$ ) conditions sampled with the total inlet. Middle and bottom panels: total fluorescent, $N_{\mathrm{F}}$, and total non-fluorescent, $N_{\mathrm{NonFl}}$, aerosol concentrations. Box and whiskers denote 5 th, 25 th, 50 th, 75th, and 95th percentiles; $x$ marker denotes mean.
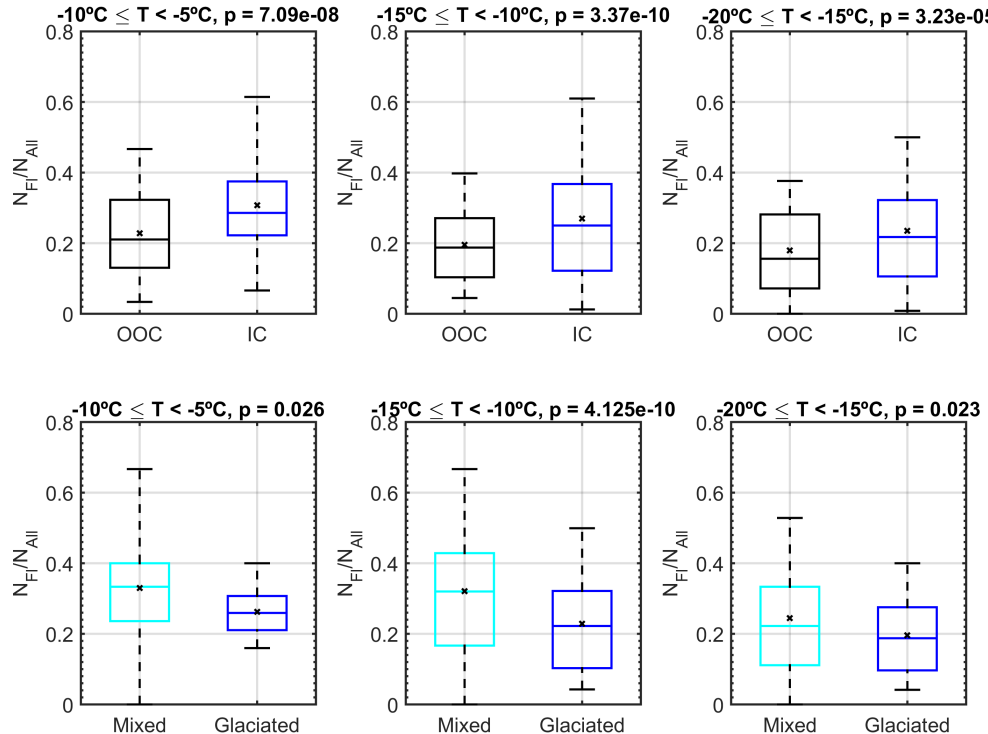

Figure 7. Top panels: influence of cloud on fluorescent fraction for the studied temperature regimes. Bottom panels: influence of cloud type on fluorescent fraction for the studied temperature regimes. Box and whiskers denote 5th, 25th, 50th, 75th, and 95th percentiles; $\mathrm{x}$ marker denotes mean. ANOVA one-way $p$ values indicated at top of each panel.

ter solution to retain, returning a three-cluster solution as shown in Fig. 12. Clusters 1 and 2 were the dominant clusters, both of which display weak fluorescence, which is characteristic of mineral dust (Pöhlker et al., 2012). The sum of particle concentrations from both clusters 1 and 2 cor- related well with the total fluorescent particle concentration $\left(\left(N_{\mathrm{cl} 1+\mathrm{cl} 2}\right)=0.3+0.94 \times N_{\mathrm{Fl}}, r^{2}=0.99\right)$ with campaign average concentrations of $1.7 \pm 3.3$ and $4.9 \pm 8.8 \mathrm{~L}^{-1}$, respectively. Cluster 3 displayed significantly higher fluorescence in all three channels suggesting that this was likely represen- 


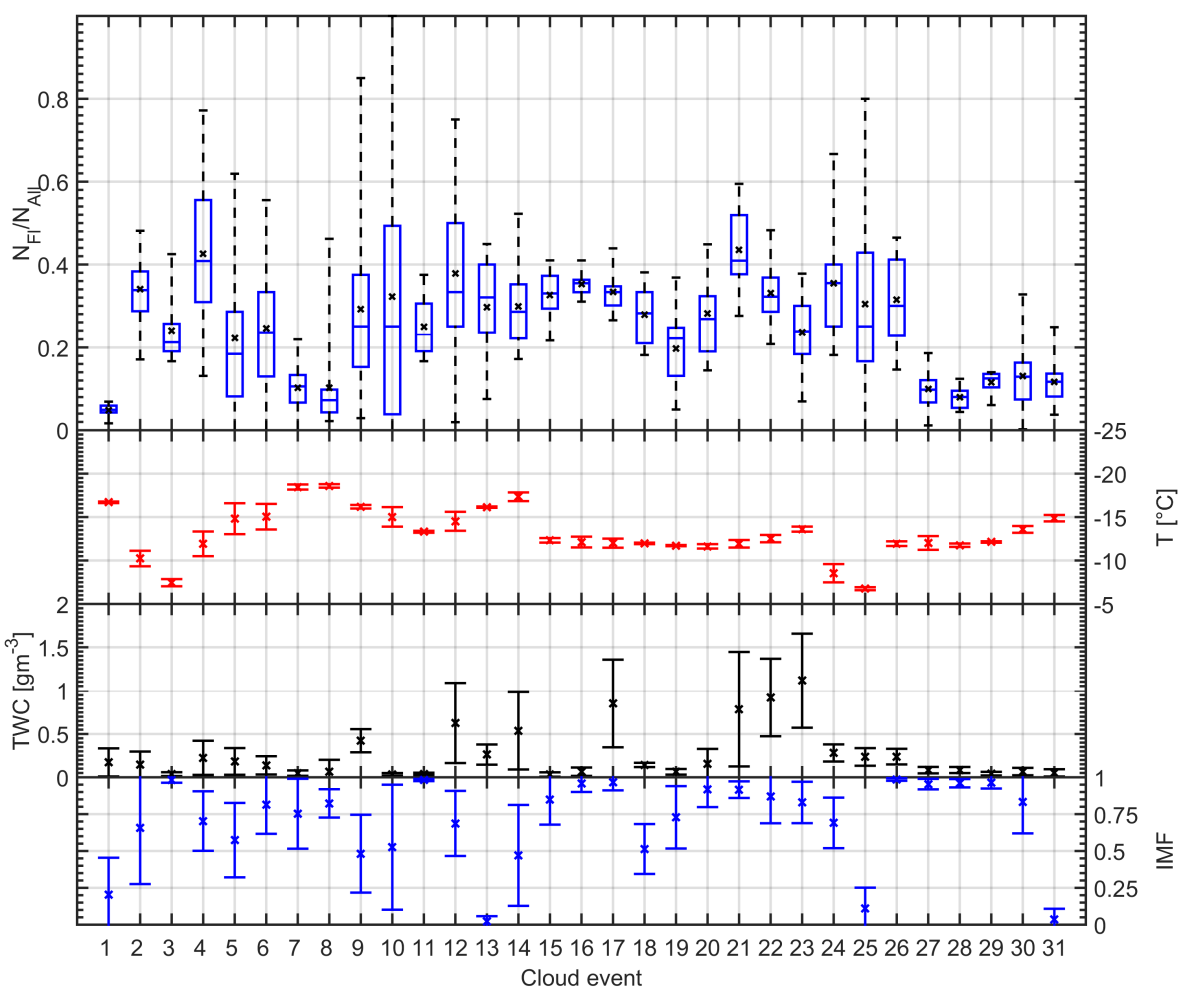

Figure 8. Box and whisker plots of fluorescent to total aerosol concentration ratio for cloud events persisting for at least 30 min in duration with accompanying temperature, total water content, and ice mass fraction measurements. Box and whiskers denote 5th, 25th, 50th, 75th, and 95th percentiles; $x$ marker denotes mean.

tative of biological material (Crawford et al., 2014). However, periods during which cluster 3 particles appeared were sparse with typical average concentrations over the period of $0.1 \pm 0.4 \mathrm{~L}^{-1}$ observed. Very occasional episodic events with maximum concentrations reaching the order of a few per litre were observed. We would expect low concentrations of local PBAP in the wintertime at this site due to reduced surface sources of seasonal PBAP coupled with an annual minimum in PBL height (Ketterer et al., 2014; Collaud Coen et al., 2011; Nyeki et al., 1998).

In summary, the majority of fluorescent aerosol sampled at the site during these periods is likely non-biological in nature with only minor episodic contributions from bioaerosols. Such low concentrations of PBAP are unlikely to have any significant impact on cloud evolution through primary ice nucleation alone due to the low ice-active fractions reported for typical PBAP; e.g. if the cluster was representative of Pseudomonas syringae (Möhler et al., 2008a) this would yield an IN concentration of only $5 \times 10^{-4} \mathrm{~L}^{-1}$, which is several orders of magnitude less than the reported ice crystal concentration (Lloyd et al., 2015); however, we can only speculate on the source of this cluster and this is used as an illustrative example only. Low concentrations of primary ice may cause glaciation via secondary mechanisms such as the Hallet-Mossop (HM) process and Wegener-Bergeron-
Findeisen (WBF) process (e.g. Crawford et al., 2012), which we now discuss in relation to this study; In this study secondary ice production via the HM process was ruled out as the clouds observed were rarely within the active temperature range for this process as discussed in the Lloyd et al. (2015) companion study; a second companion study by Farrington et al. (2015) investigated the potential influence of the WBF process at the site where they found that the critical updraft speed (as defined by Korolev and Mazin, 2003; Korolev, 2007) to maintain mixed-phase conditions was less than the observed updraft velocity for the majority of the INUPIAQ campaign using the ice 2D-S size distribution as the input for the $N_{\mathrm{i}} r_{\mathrm{i}}$ term, as such they concluded that glaciation via the WBF process was not significant. Reducing the $N_{\mathrm{i}} r_{\mathrm{i}}$ term to the typical bio-IN primary ice concentrations observed would reduce this critical threshold such that it would be significantly less than the observed updrafts.

\section{Summary and conclusions}

Analysis of $288 \mathrm{~h}$ of contemporaneous aerosol fluorescence and cloud microphysics measurements made during wintertime background conditions at a high-Alpine site revealed that the majority of aerosol sampled with a WIBS-4 UVLIF spectrometer were non-fluorescent with only $27 \%$ of 

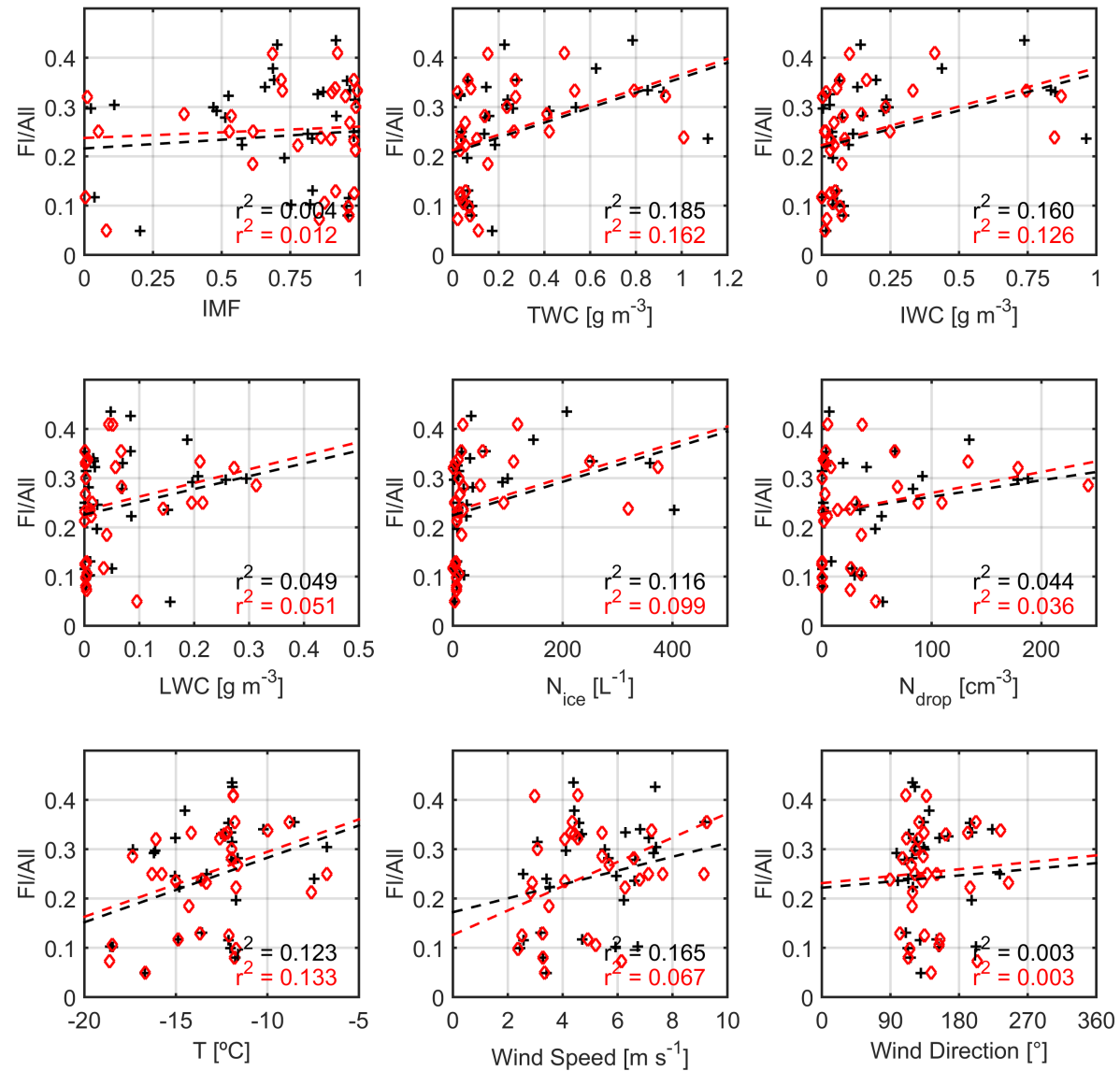

Figure 9. Correlation scatter plot of the fluorescent aerosol fraction to ice mass fraction (IMF); total water content (TWC), ice water content (IWC), liquid water content (LWC), ice crystal and droplet number concentrations, temperature, and wind speed and direction for cloud events persisting for at least $30 \mathrm{~min}$ in duration. Mean values are denoted by black + symbols and median values by red diamonds.
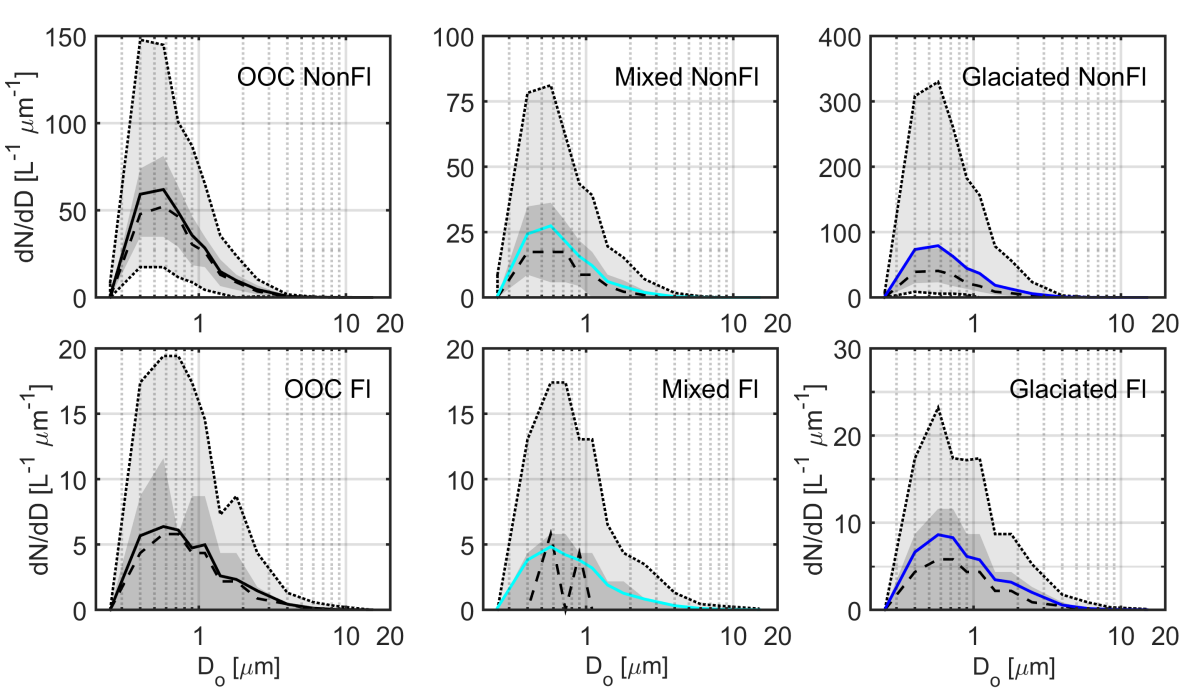

Figure 10. WIBS Non-fluorescent (top panels) and fluorescent particle size distributions (bottom panels) for (left to right panels) out-ofcloud (OOC), mixed-phase, and glaciated conditions over the temperature range $-15^{\circ} \mathrm{C} \leq T<-10^{\circ} \mathrm{C}$. Solid line is mean, dashed line is median; 5th to 95th percentiles and interquartile range shown with light and dark grey areas, respectively. 

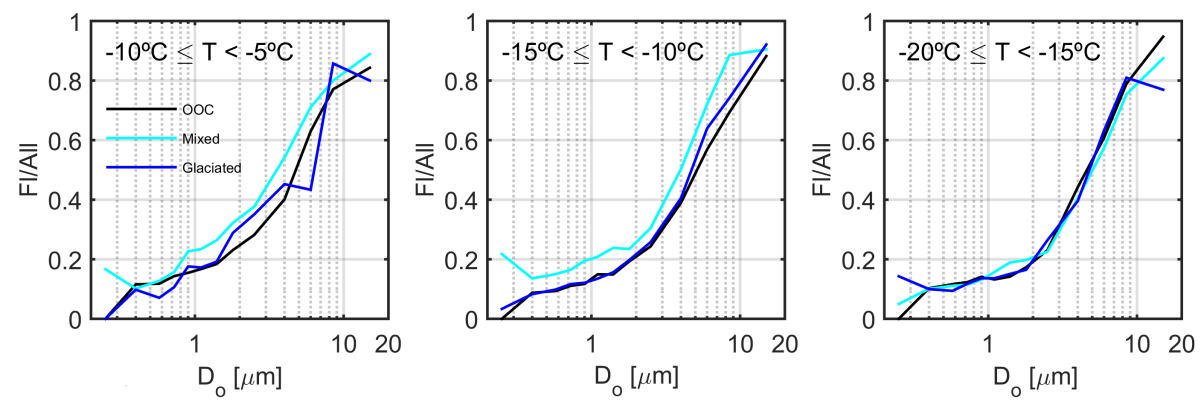

Figure 11. Size-dependent fluorescent aerosol fractions for (left to right panels) out-of-cloud (black), mixed-phase (cyan), and glaciated conditions (blue) over the three different temperature regimes studied.

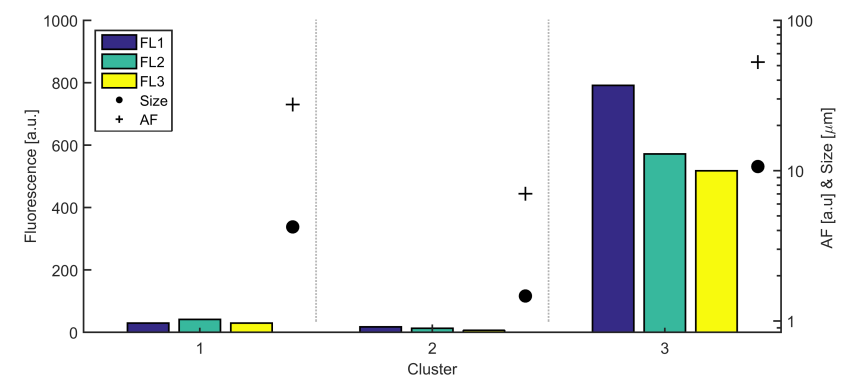

Figure 12. Mean cluster centres for the three cluster solution using Ward linkage and Calinski-Harabasz metric. Clusters contribute 25, 70 , and $5 \%$ to the fluorescent particle population.

the aerosol displaying fluorescence. We investigated the potential links between aerosol fluorescence and cloud microphysics both in general and for 31 individual cloud events persisting for at least $30 \mathrm{~min}$ and we report that there was no apparent link between the fluorescent aerosol fraction and observed cloud microphysical parameters and meteorology, suggesting that aerosol fluorescence did not influence cloud formation/evolution at the site during the measurement period.

We observed that particle fluorescence is a strong function of size with $80 \%$ of $10 \mu \mathrm{m}$ particles displaying fluorescence, decreasing to $20 \%$ at $1 \mu \mathrm{m}$. Hierarchical agglomerative cluster analysis of the fluorescent particles yielded a three-cluster solution: two of the clusters displayed fluorescent characteristics consistent with fluorescent mineral dust and these clusters accounted for approximately $95 \%$ of the observed fluorescent particles. The remaining cluster was moderately fluorescent in all three channels and is assumed to be biological in origin. Concentrations of the assumed PBAP cluster were sparse, occurring in occasional minor episodes with a baseline concentration of $0.1 \pm 0.4 \mathrm{~L}^{-1}$. Given the low concentration of this cluster and the typically low ice-active fraction of studied PBAP (e.g. Pseudomonas syringae; Möhler et al., 2008a), we suggest that the contribution to the observed ice crystal concentration at this location is not significant during the wintertime. Analysis of wind speed and direction sug- gests that large emissions from sources from the Po Valley region may advect up the Aletsch glacier during periods of high wind speed, which may be of significance during the summer when the PBL is higher. We suggest that longer-term data sets are required to examine this in detail.

\section{The Supplement related to this article is available online at doi:10.5194/acp-16-2273-2016-supplement.}

Acknowledgements. This work was funded by the NERC INUPIAQ programme, grant number NE/K006002/1. The data used in this manuscript can be accessed from the British Atmospheric Data Centre. HYPLIT data were obtained from the NOAA Air Resource Laboratory (http://ready.arl.noaa.gov/). We would like to thank the International Foundation High-Altitude Research Stations Jungfraujoch and Gornergrat (HFSJG) for providing the support in carrying out experiments at Jungfraujoch and the ACTRIS-TNA project for contributing towards the project infrastructure. Aerosol monitoring is supported by MeteoSwiss in the framework of the Global Atmosphere Watch (GAW) programme. Further funding was provided by FP7 project BACCHUS (grant agreement no. 603445). C. Hoyle was funded by the Swiss National Science Foundation, SNSF grant number 200021_140663.

Edited by: B. Ervens

\section{References}

Baltensperger, U., Schwikowski, M., Jost, D. T., Nyeki, S., Gaggeler, H. W., and Poulida, O.: Scavenging of atmospheric constituents in mixed phase clouds at the high-alpine site Jungfraujoch part I: Basic concept and aerosol scavenging by clouds, Atmos. Environ., 32, 3975-3983, doi:10.1016/S13522310(98)00051-X, 1998.

Chernoff, D. I. and Bertram, A. K.: Effects of sulfate coatings on the ice nucleation properties of a biological ice nucleus and several types of minerals, J. Geophys. Res., 115, D20205, doi:10.1029/2010JD014254, 2010.

Choularton, T. W., Bower, K., Weingartner, E., Crawford, I., Coe, H., Gallagher, M. W., Flynn, M., Crosier, J., Connolly, P., 
Targino, A., Alfarra, M. R., Baltensperger, U., Sjogren, S., Verheggen, B., Cozic, J., and Gysel, M.:The influence of small aerosol particles on the properties of water and ice clouds, Faraday Discuss., 137, 205-222, doi:10.1039/b702722m, 2008.

Collaud Coen, M., Weingartner, E., Furger, M., Nyeki, S., Prévôt, A. S. H., Steinbacher, M., and Baltensperger, U.: Aerosol climatology and planetary boundary influence at the Jungfraujoch analyzed by synoptic weather types, Atmos. Chem. Phys., 11, 5931-5944, doi:10.5194/acp-11-5931-2011, 2011.

Cozic, J., Verheggen, B., Mertes, S., Connolly, P., Bower, K., Petzold, A., Baltensperger, U., and Weingartner, E.: Scavenging of black carbon in mixed phase clouds at the high alpine site Jungfraujoch, Atmos. Chem. Phys., 7, 1797-1807, doi:10.5194/acp-7-1797-2007, 2007.

Crawford, I., Bower, K. N., Choularton, T. W., Dearden, C., Crosier, J., Westbrook, C., Capes, G., Coe, H., Connolly, P. J., Dorsey, J. R., Gallagher, M. W., Williams, P., Trembath, J., Cui, Z., and Blyth, A.: Ice formation and development in aged, wintertime cumulus over the UK: observations and modelling, Atmos. Chem. Phys., 12, 4963-4985, doi:10.5194/acp-12-4963-2012, 2012.

Crawford, I., Robinson, N. H., Flynn, M. J., Foot, V. E., Gallagher, M. W., Huffman, J. A., Stanley, W. R., and Kaye, P. H.: Characterisation of bioaerosol emissions from a Colorado pine forest: results from the BEACHON-RoMBAS experiment, Atmos. Chem. Phys., 14, 8559-8578, doi:10.5194/acp-14-8559-2014, 2014.

Crawford, I., Ruske, S., Topping, D. O., and Gallagher, M. W.: Evaluation of hierarchical agglomerative cluster analysis methods for discrimination of primary biological aerosol, Atmos. Meas. Tech. Discuss., 8, 7303-7333, doi:10.5194/amtd-8-7303-2015, 2015.

Crosier, J., Bower, K. N., Choularton, T. W., Westbrook, C. D., Connolly, P. J., Cui, Z. Q., Crawford, I. P., Capes, G. L., Coe, H., Dorsey, J. R., Williams, P. I., Illingworth, A. J., Gallagher, M. W., and Blyth, A. M.: Observations of ice multiplication in a weakly convective cell embedded in supercooled mid-level stratus, Atmos. Chem. Phys., 11, 257-273, doi:10.5194/acp-11-257-2011, 2011.

Crosier, J., Choularton, T. W., Westbrook, C. D., Blyth, A. M., Bower, K. N., Connolly, P. J., Dearden, C., Gallagher, M. W., Cui, Z., and Nicol, J. C.: Microphysical properties of cold frontal rainbands, Q. J. Roy. Meteorol. Soc., 140, 1257-1268, doi:10.1002/qj.2206, 2014.

Cziczo, D. J., Froyd, K. D., Gallavardin, S. J., Moehler, O., Benz, S., Saathoff, H., and Murphy, D. M.: Deactivation of ice nuclei due to atmospherically relevant surface coatings, Environ. Res. Lett., 4, 044013, doi:10.1088/1748-9326/4/4/044013, 2009.

DeLeon-Rodriguez, N., Lathem, T. L., Rodriguez-R, L. M., Barazesh, J. M., Anderson, B. E., Beyersdorf, A. J., Ziemba, L. D., Bergin, M., Nenes, A., and Konstantinidis, K. T.: Microbiome of the upper troposphere: species composition and prevalence, effects of tropical storms, and atmospheric implications, P. Natl. Acad. Sci. USA, 110, 2575-2580, doi:10.1073/pnas.1212089110, 2013.

Eastwood, M. L., Cremel, S., Gehrke, C., Girard, E., and Bertram, A. K.: Ice nucleation on mineral dust particles: onset conditions, nucleation rates and contact angles, J. Geophys. Res., 113, D22203, doi:10.1029/2008JD010639, 2008.

Farrington, R. J., Connolly, P. J., Lloyd, G., Bower, K. N., Flynn, M. J., Gallagher, M. W., Field, P. R., Dearden, C., and Choularton,
T. W.: Comparing model and measured ice crystal concentrations in orographic clouds during the INUPIAQ campaign, Atmos. Chem. Phys. Discuss., 15, 25647-25694, doi:10.5194/acpd-1525647-2015, 2015.

Gabey, A. M., Stanley, W. R., Gallagher, M. W., and Kaye, P. H.: The fluorescence properties of aerosol larger than $0.8 \mu \mathrm{m}$ in urban and tropical rainforest locations, Atmos. Chem. Phys., 11, 5491-5504, doi:10.5194/acp-11-5491-2011, 2011.

Gabey, A. M., Vaitilingom, M., Freney, E., Boulon, J., Sellegri, K., Gallagher, M. W., Crawford, I. P., Robinson, N. H., Stanley, W. R., and Kaye, P. H.: Observations of fluorescent and biological aerosol at a high-altitude site in central France, Atmos. Chem. Phys., 13, 7415-7428, doi:10.5194/acp-13-7415-2013, 2013.

Govindarajan, A. G. and Lindow, S. E.: Size of bacterial icenucleation sites measured in situ by radiation inactivation analysis, P. Natl. Acad. Sci. USA, 85, 1334-1338, 1988.

Heintzenberg, J., Okada, K., and Ström, J.: On the composition of non-volatile material in upper tropospheric aerosols and cirrus crystals, Atmos. Res., 41, 81-88, doi:10.1016/01698095(95)00042-9, 1996.

Herrmann, E., Weingartner, E., Henne, S., Vuilleumier, L., Bukowiecki, N., Steinbacher, M., Conen, F., Collaud Coen, M., Hammer, E., Jurànyi, Z., Baltensperger, U., and Gysel, M.: Analysis of long-term aerosol size distribution data from Jungfraujoch with emphasis on free tropospheric conditions, cloud inluence, and air mass transport, J. Geophys. Res.-Atmos., 120, 9459-9480, doi:10.1002/2015JD023660, 2015.

Hoose, C. and Möhler, O.: Heterogeneous ice nucleation on atmospheric aerosols: a review of results from laboratory experiments, Atmos. Chem. Phys., 12, 9817-9854, doi:10.5194/acp-12-98172012, 2012.

Huffman, J. A., Prenni, A. J., DeMott, P. J., Pöhlker, C., Mason, R. H., Robinson, N. H., Fröhlich-Nowoisky, J., Tobo, Y., Després, V. R., Garcia, E., Gochis, D. J., Harris, E., Müller-Germann, I., Ruzene, C., Schmer, B., Sinha, B., Day, D. A., Andreae, M. O., Jimenez, J. L., Gallagher, M., Kreidenweis, S. M., Bertram, A. K., and Pöschl, U.: High concentrations of biological aerosol particles and ice nuclei during and after rain, Atmos. Chem. Phys., 13, 6151-6164, doi:10.5194/acp-13-6151-2013, 2013.

Kajava, A. V. and Lindow, S. E.: A model of the three-dimensional structure of ice nucleation proteins, J. Mol. Biol., 232, 709-717, doi:10.1006/jmbi.1993.1424, 1993.

Kamphus, M., Ettner-Mahl, M., Klimach, T., Drewnick, F., Keller, L., Cziczo, D. J., Mertes, S., Borrmann, S., and Curtius, J.: Chemical composition of ambient aerosol, ice residues and cloud droplet residues in mixed-phase clouds: single particle analysis during the Cloud and Aerosol Characterization Experiment (CLACE 6), Atmos. Chem. Phys., 10, 8077-8095, doi:10.5194/acp-10-8077-2010, 2010.

Kaye, P. H., Stanley, W. R., Hirst, E., Foot, E. V., Baxter, K. L., and Barrington, S. J.: Single particle multichannel bio-aerosol fluorescence sensor, Opt. Express, 13, 3583, doi:10.1364/OPEX.13.003583, 2005.

Ketterer, C., Zieger, P., Bukowiecki, N., Collaud Coen, M., Maier, O., Ruffieux, D., and Weingartner, E.: Investigation of the planetary boundary layer in the Swiss Alps using remote sensing and in situ measurements, Bound.-Lay. Meteorol., 151, 317-334, doi:10.1007/s10546-013-9897-8, 2014. 
Koehler, K. A., Kreidenweis, S. M., DeMott, P. J., Petters, M. D., Prenni, A. J., and Möhler, O.: Laboratory investigations of the impact of mineral dust aerosol on cold cloud formation, Atmos. Chem. Phys., 10, 11955-11968, doi:10.5194/acp10-11955-2010, 2010.

Korolev, A. V. and Mazin, I. P.: Supersaturation of Water Vapor in Clouds, J. Atmos. Sci., 60, 2957-2974, doi:10.1175/15200469(2003)060<2957:SOWVIC>2.0.CO;2, 2003.

Korolev, A. V.: Limitations of the Wegener-Bergeron-Findeisen Mechanism in the Evolution of Mixed-Phase Clouds, J. Atmos. Sci., 64, 3372-3375, doi:10.1175/JAS4035.1, 2007.

Lance, S., Brock, C. A., Rogers, D., and Gordon, J. A.: Water droplet calibration of the Cloud Droplet Probe (CDP) and inflight performance in liquid, ice and mixed-phase clouds during ARCPAC, Atmos. Meas. Tech., 3, 1683-1706, doi:10.5194/amt3-1683-2010, 2010.

Lawson, R. P., Woods, S., and Morrison, H.: The microphysics of ice and precipitation development in tropical cumulus clouds, J. Atmos. Sci., 72, 2429-2445, doi:10.1175/JAS-D-14-0274.1, 2015.

Lloyd, G., Choularton, T. W., Bower, K. N., Gallagher, M. W., Connolly, P. J., Flynn, M., Farrington, R., Crosier, J., Schlenczek, O., Fugal, J., and Henneberger, J.: The origins of ice crystals measured in mixed phase clouds at High-Alpine site Jungfraujoch, Atmos. Chem. Phys. Discuss., 15, 18181-18224, doi:10.5194/acpd-15-18181-2015, 2015.

Möhler, O., Georgakopoulos, D. G., Morris, C. E., Benz, S., Ebert, V., Hunsmann, S., Saathoff, H., Schnaiter, M., and Wagner, R.: Heterogeneous ice nucleation activity of bacteria: new laboratory experiments at simulated cloud conditions, Biogeosciences, 5, 1425-1435, doi:10.5194/bg-5-1425-2008, 2008a.

Möhler, O., Benz, S., Saathoff, H., Schnaiter, M., Wagner, R., Schneider, J., Walter, S., Ebert, V., and Wagner, S.: The effect of organic coating on the heterogeneous ice nucleation efficiency of mineral dust aerosols, Environ. Res. Lett., 3, 025007 , doi:10.1088/1748-9326/3/2/025007, 2008b.

Morris, C. E., Conen, F., Alex Huffman, J., Phillips, V., Pöschl, U., and Sands, D. C.: Bioprecipitation: a feedback cycle linking earth history, ecosystem dynamics and land use through biological ice nucleators in the atmosphere, Global Change Biol., 20, 341-351, doi:10.1111/gcb.12447, 2014.

Nyeki, S., Li, F., Weingartner, E., Streit, N., Colbeck, I., Gäggeler, H. W., and Baltensperger, U.: The background aerosol size distribution in the free troposphere: an analysis of the annual cycle at a high-alpine site, J. Geophys. Res., 103, 31749, doi:10.1029/1998JD200029, 1998.
Penner, J., Andreae, M., Annegarn, H., Barrie, L., Feichter, J., Hegg, D., Jayaraman, A., Leaitch, R., Murphy, D., Nganga, J., and Pitari, G.: Climate Change 2001: The Scientific Basis: Chapter 6 Radiative Forcing of Climate Change, IPCC report, Cambridge University Press, Cambridge, UK and New York, NY, USA, 2001.

Pöhlker, C., Huffman, J. A., and Pöschl, U.: Autofluorescence of atmospheric bioaerosols - fluorescent biomolecules and potential interferences, Atmos. Meas. Tech., 5, 37-71, doi:10.5194/amt-537-2012, 2012.

Sassen, K., DeMott, P. J., Prospero, J. M., and Poellot, M. R.: Saharan dust storms and indirect aerosol effects on clouds: CRYSTAL-FACE results, Geophys. Res. Lett., 30, 1633, doi:10.1029/2003GL017371, 2003.

Stanley, W. R., Kaye, P. H., Foot, V. E., Barrington, S. J., Gallagher, M., and Gabey, A.: Continuous bioaerosol monitoring in a tropical environment using a UV fluorescence particle spectrometer, Atmos. Sci. Lett., 12, 195-199, doi:10.1002/as1.310, 2011.

Sullivan, R. C., Petters, M. D., DeMott, P. J., Kreidenweis, S. M., Wex, H., Niedermeier, D., Hartmann, S., Clauss, T., Stratmann, F., Reitz, P., Schneider, J., and Sierau, B.: Irreversible loss of ice nucleation active sites in mineral dust particles caused by sulphuric acid condensation, Atmos. Chem. Phys., 10, 1147111487, doi:10.5194/acp-10-11471-2010, 2010.

Targino, A. C., Coe, H., Cozic, J., Crosier, J., Crawford, I., Bower, K., Flynn, M., Gallagher, M., Allan, J., Verheggen, B., Weingartner, E., Baltensperger, U., and Choularton, T.: Influence of particle chemical composition on the phase of cold clouds at a high-alpine site in Switzerland, J. Geophys. Res., 114, D18206, doi:10.1029/2008JD011365, 2009.

Verheggen, B., Cozic, J., Weingartner, E., Bower, K., Mertes, S., Connolly, P., Gallagher, M., Flynn, M., Choularton, T., and Baltensperger, U., J. Geophys. Res.-Atmos., 104, 26809-26820, 1999.: Aerosol partitioning between the interstitial and condensed phase in mixed-phase clouds, J. Geophys. Res., 112, D23202, doi:10.1029/2007JD008714, 2007.

Weingartner, E., Nyeki, S., and Baltensperger, U.: Seasonal and diurnal variation of aerosol size distributions $(10<D<750 \mathrm{~nm})$ at a high-alpine site (Jungfraujoch $3580 \mathrm{~m}$ asl), J. Geophys. Res.Atmos., 104, 26809-26820, doi:10.1029/1999JD900170 1999. 